\title{
複 合化
}

\section{1. はじめに}

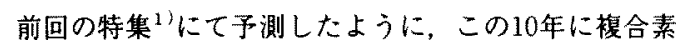
材はその技術を著しく离度化し，多様化したニーズに対 応してきた。10年前までの動向は前報を参考にしていた だき，本報では1984年から1993年までの技術動向を述べ る。

まず、この10年で特筆すべきこととして，フィラメン ト間での複合技術として1988年頃より始まった新合瀻 プームを挙げることができる。これにより衣料轼維にお ける高付加価值製品への志向が一段と加速されたが、こ の新合辀ブームが落ちつきを見せた現在でも、フィラメ

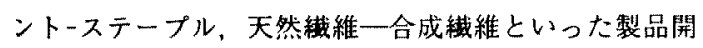
発が以前にも增して活発に行われている2)。 その背景には，

(1) ファッショントレント゚の変化に備え, 素材開発が活 性化した事

（2）新合轿で培われてきた技術の水平展開が始まった事 があるのではないだろうか。このような状況の下，複 合化技術は大きな可能性を見出され，高度に深化して 来ている。

\section{2. 襩合形態の分類}

複合形態の分類に関する新しい提案もあるが3!,ここ ではその複合構造から下記 4 形態に分類してみだ。

(1) 単樴維内複合

(2) 单䄉維間複合(ヤーン内複合)

(3) 布帛内複合(ヤーン間複合)

(4) 衣服内複合 (布帛間複合)

布帛内複合及び衣服内複合に関しては，前報同様他に 述ベられるのでこれを参考にしていただくとして、ここ では前報と同様に単織維内複合と単䋊維閒複合を対象と する。

一方，この分類からはずれた，拡大概念も目立ってき ている。

そのひとつは，前報で述べた分子内複合であり，ポリ マー段階からの改質が盛んに行われている。ただしここ
安田浩・山中昌 樹

れに関しては本特集号の䄉維素材の項で述べられるであ ろうから割爱する。

また，前記の分類が，製糸，編織工程を重視した横方 向の技術分類であるのに对し，原料から染色後加工にわ たる綎方向の複合化技術という概念も目立って来てい る。これについては後に述べることにする。

\section{3. 複合化技術の功向}

各種複合形態において用いられる複合化技術の観点か ら，単䄳維内複合に関しては，異成分を緎維中に混合す る混合紡系技術と, 複合押出しを用いる複合紡系技術に 分類できる。また単䄉維間複合に関しては、フィラメン 卜同士の複合(F-F 複合), フィラメントとステープル 間の複合 (F-S 複合), ステープル同士の複合( $\mathrm{S}-\mathrm{S}$ 複合) の 3 技術に分類できる。各複合化技術に関し，この10年 間に新閶紙上に揭載された新素材発表の動向(件数)を図 $1 ， 2$ に示した。

まず全体的に，この $2 ， 3$ 年の新素材開発が特に著し

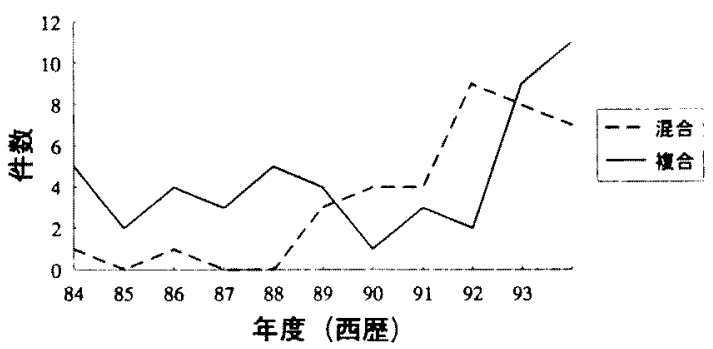

図1 単織維内複合

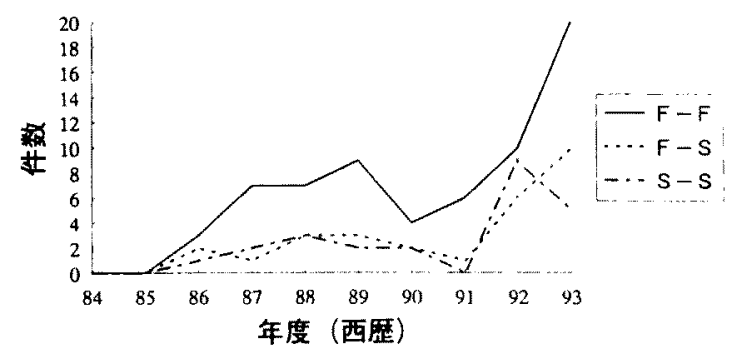

図2 単䄉維間複合 
い事が挙げられる。近年ファッショントレンドの変化が 現れ始め，天然織維がらみの開発が活性化しただけでな く，合成縺維も新合織の開発で培った複合化技術を用い て素材对応を活性化しているためと考えられる。

次に1988年を中心として，新合樴ブームの始まりに対 応するF-F 複合素材の開発ピークと，1985年から1988 年まで続く超極細䄉維ブームに対応する複合紡采技術の ピークがそれぞれ影著に見られることは特記すべきであ ろう。

次にここの10年間で特に目立った技術動向を説明す る。

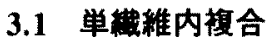

複合紡系技術に関する素材開発は，1985年頃から著し く活発化している。当初, 超極細鐵維を得るための手段 として用いられ，超極細織維使いのワイビンタクロス ブームに各社が对応したためであろう。

基本技術は以前からあり，極細化処理の手法から一成 分溶出型5) と, 界面剥離型的に分けることが出来る。

また，衣料用稢維としての展開も進み，薄起毛調新合 縅の一つの技術要素となった。用いられる複合断面形態 は複雑さを深め7，単に超極細轹維を得るだけでなく， 嬂維表面にスリットを与えたり めの手段として展開されている。様々な断面を持つ複合 䄉維が開発されているが, 複合紡系ノズル製造技術しべ ルが高度化したことも重要な要素である。

混合紡糸技術に関する開発も1991年頃より盛んで, 鐵 維表面に微細な凹凸を付与する手段として用いられるも のと、種々の機能を有する粒子を織維中に混入するもの がある。この基本技術もすでに1980年以前に確立されて いるが、機能性付与を意図した設計がなされ，それによ る応用展開が計られている ${ }^{10)} 。$ 特に, 複合化の一要素 技術として，他の複合技術と共用される事が多くなって いる。

\section{2 単識維間複合}

1987年から1989年にかけて F-F 複合系が多く開発さ れている事が特徽的である。この範疇に属するものは， 新合阵として扱われることが多く，新合戟ブームの原動 力となった。1992，1993年には再び著しい增加が見ら れ，新合織に替わる素材の開発を各社共勢力的に行って いるようである。

複合化技術としては，大きく混鐵技術を主体とするも のと，仮撚加工技術を主体とするものに分類することが 出来る。

混䄉技術に関しては，ふくらみの追求がなされ，異収 縮混䄾を基本技術として，新たな技術開発が行われた。

まず栜長差の発現性を著しく改善したものが87年から
見られ新合轼の走りとなっだ11。系長差に関する検討 は更に進み，収縮を多段に発生させる技術もみられる 12)。また，単純な混较技術に関しても，異種ポリ マー, 異形状, 異染色性等素材混合中心にバラエティー 豊かに展開されている13)。

仮撚加工技術に関するものは，発表件数が非常に多 い。基本技術は複合仮撚加工であり，エアー交絡処理を 施したり、デニール構成を变え収縮率差を持たせたもの 14)，また毛羽を付与しスパン調としたもの ${ }^{15}$ )等様々な ヴァリエーションがある。禾構造も二層構造あるいは多 層構造の仮撚加工糸, 港回仮撚加工系, 多重捲縮仮撚加 工糸等様々である。これら要素技術の用い方にはノウハ ウ的な部分が多く詳細が不明なものが多いのも特徽とい える。

単織維間複合に関し，もう一つの特記すべき動向があ る。この 2 年の間に F-S 複合が急激に注目を集め始め

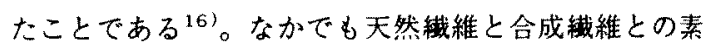
材複合が目立つ ${ }^{17)}$ 。技術的には, 電気開鐵方式を用い

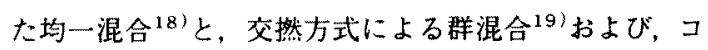
アスパンによる2層構造 ${ }^{20)}$ の 3 種に分類できる。また 多重構造を用いた快適素材設計の例もある ${ }^{21) 。 ~}$

また単樴維間複合の分類からは外れるが，F-S 交織に よる開発も活発になっている22)。

\section{3 高次複合}

製系における複合化技術について主に述べてきたが， 新たな複合化の概念がこの10年に生まれている。即方， 製系一後加工一染色の各工程間の連携が新合織の開発に 際し行われ，工程間複合というべき概念が生まれたこと

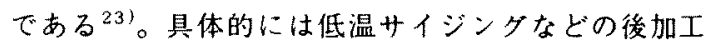
や，染色，仕上加工に扔ける低張力加工等の轼細な配虑 であり ${ }^{24)}$ この連携無くしては，現在の新合鐵の成功 はなかったといえる。

またこれとは別に複合化技術を組み合わせた例が多く 見られ，複雑さを增している。いってみれば技術間複合 である。ごく一例を挙げれば，複合紀系と混轹技術の混 用 ${ }^{25)}$ や, 混合紡采と蓠高加工の混用 ${ }^{26)}$ などで実際数え ればきりがない。

\section{4. 複合化技術の展望}

先にも述べたようにこの $2 ， 3$ 年の複合化技術開発 の状況には目を見張るものがある。

また, 複合の形態と機能も、複合技術間(横方向)や工 程間(縦方向)での複合のように概念が拡大され、複雑さ を增している。

今後も技術的進歩は続くであろうが，素材の選択にも 未知の可能性があると思われる。過去には無かった新概 
念を、素材の複合によって創出した例をカバリングパン

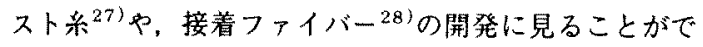
きる。

複合する素材の組み合わせとしては，機能性差，物性 差の大きいものほど複合により得られる効果は顕著であ クこの意味で天然䄉維と合成䋞維の複合はメリットが 大きく，今後も盛んな開発が続くであろう。

また，新素材が出てくれば，著しく多彩なバリエーシ ヨンが可能となる。多様化されたニーズに対応した，素 材及び複合化技術の選択と言う開発形式が今後も進んで 行くのではないだろうか。

\section{参考文献}

1) 安田 浩：轿学誌, 40, P-312 -314 (1984).

2) 加工技術, 28, 345 - 375 (1993).

3 ) 島倉 堡：䄉学誌, 48, P-126〜133 (1992).

市樯邦夫，テキスタイル複合素材の実際知識, p13 p21. (1992).

4) 一志道生, 原田隆司：染色工業, 32, P 5 - 14 . (1984)

5) 東レ：特公昭44-13208, クラレ：特公昭53-22169,

6) 鐘紡：特公昭49-29129, 帝人：特公昭53-10169.

7）例之ば，鐘紡：日経，90,5，1，ユニチ力：峨研, $91,8,14$

8 ) 東レ：機研 $88,8,25$.

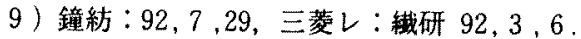

10）例えばクラレ：日轼， $88 ， 6 ， 4$, 東洋紡：日緎, $88,6,21$.

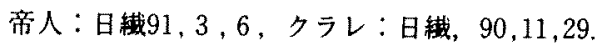

11）東レリサーチ：機能性緎維，P278～280. (1993)

12）例えば，東レ：日緁， $89,10,4$.

13）例えば,クラレ：日織，92，3，5, 東レ：䄉研, $93,7,20$.

14）例えば, 東レ：日䄉， $88 ， 2 ， 18$, 帝人：桟研, $91,12,10$.

15）例えば, 帝人：化学工業日報, $92,9,18$.

16) 緉研, $91,9,19$.

17）加工技術，28，345 375（1993).

18)福岡重紀：䄉学誌, 48, P-319－321 (1992).

19）例之ば，帝人：䋞研， $92,12,19$.

20）例えば，東レ：日戟，86，1，14.

21）例えば，東洋紡：日械， $83 ， 8 ， 31$.

22）例元ば，鐘紡：日悈，92,11,26.

23) 䄉研, $91,1,4$.

24）加工技術，28，380 429 (1993).

25）例えば，東レ：日䄉， $93,11,29$.

26）例之ば，帝人：轼研，93，9，8

27）例えば，東レ：日経産， $63,12,2$.

28）例之ば，鐘紡：浅研， $84 ， 3,14$.

(平成 6 年 3 月 3 日受理) 